\title{
DARBUOTOJŲ VERTINIMO İTAKA ORGANIZACIJOS MOKYMUISI LAISVALAIKIO SPORTO KLUBUOSE
}

\author{
Edmundas Jasinskas ${ }^{1}$, Biruta Švagždiené2 ${ }^{2}$ Rimantas Mikalauskas ${ }^{3}$ \\ ${ }^{1}$ Lietuvos kūno kultūros akademija, Lietuva, edmundas.jasinskas@gmail.com \\ ${ }^{2}$ Lietuvos kūno kultūros akademija, Lietuva, b.svagzdiene@gmail.com \\ ${ }^{3}$ Lietuvos kūno kultūros akademija,Lietuva,r.mikalauskas@lkka.lt \\ cross $^{\text {ref http://dx.doi.org/10.5755/j01.em.17.4.3000 }}$
}

\begin{abstract}
Recently the scientists (Stewart (2001), Phillips (2003), Aksu \& Özdemir (2005); Senge, 2008) analyzing the concept of the organization in the process learning give great attention to the consideration of means of organization activity improvement and possibilities of competitive ability increase. One of the most significant possibilities of activity improvement is the evaluation of employees' activity. Therefore it is very important to ascertain what relation there is between evaluation of employees and organizational learning.

Objective of the research - to determine the influence of employees' evaluation on organizational learning at leisure \& sports clubs.

Methods used: analysis of scientific literature (in order to systematize the approach of the representatives of organization theory in the process of learning), questionnaire (managers and specialists of sports clubs of Alytus city), descriptive statistical analysis (systematizing data of questionnaire).

Restrictions of the empirical research. Questionnaire was carried out one time, i.e., on FebruaryJanuary of 2010, and was not repeated any more.

Employees, i.e. instructors of sports club of Alytus city, were questioned during the research. There were 9 leisure sports clubs fully performing their activities (22 instructors working) in Alytus city and there were 21 respondents questioned.

Research results: After the analysis of questionnaire data of the employees from sports organizations, it was determined that evaluation of employees' activity of sports organizations is performed regularly, however there is lack of knowledge presentation about evaluation criteria to employees.

Team (structured) evaluation methods affect the analysis of work performed in the organization more than individual (descriptive) methods. When applying team (structured) and individual (descriptive) evaluation methods, knowledge at work is applied more practically than expressed in words, numbers and symbols. The more often employees' activity is evaluated, the more rarely the persons being analyzed are seeking for information themselves. When performing team evaluation at the organization, the features of organization in the process of learning are more highlighted than after evaluation of the link between the features mostly corresponding to the organization, and the most acceptable factors inducing learning. Although under different intensity, all analyzed aspects of activity evaluation are influencing organizational learning of employees, especially team methods of employees' evaluation.

Usually the function of activity evaluation at leisure and sports clubs of Alytus city is performed by immediate manager. However, there is lack of knowledge presentation about evaluation criteria to the employees. This negatively affects the attitude of employees to evaluation process. Evaluation is usually carried out on a team level with the help of special methods but individual methods are not excluded either. Therefore, the evaluation method should be chosen by every sports organization individually. The positive effect of activity evaluation on the experience and knowledge control and the spread was determined. The aspects named have the influence on the results of organization activity. Therefore, a particular focus should given to the function of evaluation of employees' activity, particularly when seeking for the increase of competitive advantage.
\end{abstract}

Keywords: Employees' evaluation, organizational learning, leisure \& sports clubs.

JEL Classification: D23, M12, M14, M21, M53, M54.

\section{Ivadas}

Pastebima vieninga nuomonė (Stukalina, 2010; Serafinas \& Ruževičius, 2009; Ginevicius \& Gineviciene, 2009; Grundey, 2008; Zafiropoulos \& Vrana, 2008; Jasinskas, 2008; Neverauskas \& Stankevicius, 2008), jog individualus ir organizacijos mokymosi ịvertinimas yra itin sudètingas procesas. A.Örtenblad (2001), D.Stewart (2001), B.T.Phillips (2003), A.Aksu \& B.Özdemir (2005), akcentuoja besimokančios organizacijos esmę ir teigia, kad besimokančios organizacijos modeli įdiegti praktikoje yra labai sunku. Minètų mokslininkų darbuose didelis dėmesys skiriamas tradicinès organizacijos transformacijai i besimokančią organizaciją.

Mokslinė problema - Norint išlikti organizacijai konkurencingai ji privalo nuolat mokytis ir kaupti žinias. Organizacijos mokymasis nors ir nèra tapatus individualiam, tačiau glaudžiai susiejęs su individualiu mokymusi. Paprastai darbuotojas elgiasi pagal tai už ką yra vertinimas, todèl viena iš svarbių sąlygų nuolatiniam organizacijos ir atskiro darbuotojo mokymuisi yra tinkamas darbuotoju įvertinimas. Paprastai 
stambios organizacijos turi didesnes galimybes pasamdyti žmogiškujų išteklių valdymo specialistus, tuo tarpu žymiai sudètingiau tinkamai ir objektyviai darbuotojus vertinti nedidelèse organizacijose, prie tokių organizacijų galima priskirti laisvalaikio sporto klubus. Tyrime siekiama įvertinti kokie Alytaus laisvalaikio sporto klubų darbuotojų vertinimo metodai labiau ịtakoja organizacijos tapsmą besimokančia organizacija. klubuose.

Straipsnio tikslas - nustatyti darbuotojų vertinimo įtaką organizacijos mokymuisi laisvalaikio sporto klubuose.

Tyrimo objektas - darbuotojų ịvertinimo ịtaka organizacijos mokymuisi Alytaus laisvalaikio sporto

Naudoti metodai. Mokslinès literatūros analizė (siekiant susisteminti besimokančios organizacijos teorijos atstovų požiūrị ị darbuotojų įvertinimo ịtaką mokymuisi), anketinè apklausa (Alytaus laisvalaikio sporto klubų vadovai ir specialistai), aprašomosios statistikos analizė (sisteminant anketinès apklausos duomenis).

Empirinio tyrimo apribojimai. Anketinė apklausa atlikta vieną kartą, t.y. 2010 metų sausio - vasario mènesiais, ir daugiau nekartota.

Tyrime apklausti Alytaus sporto klubo darbuotojai - treneriai. Tyrimo metu Alytuje aktyvią veiklą vykdė 9 laisvalaikio sporto klubai (juose dirbo 22 treneriai), apklaustas 21 respondentas.

\section{Darbuotojų vertinimo įtaka organizacijos mokymuisi: teorinis aspektas}

Mokslinèje literatūroje (Slizyte \& Bakanauskiene, 2007; Alonderienė \& Bakanauskienė, 2004) išskiriami pagrindiniai darbuotojų vertinimo metodai išskaidant ị individualius (360 laipsnių grižtamojo ryšio, individualaus vertinimo, laisvi (nestruktūrizuoti), aprašomieji (kokybiniai), kombinuotieji (tarpiniai), kiekybiniai) ir komandinius (lyginamojo vertinimo, struktūrizuoti, specialieji). Išskirti individualių metodų privalumai: aiškus vertintojų skaičius, darbuotojai vertinami kiekvienas individualiai, nustatytas griežtas kriterijų kompleksas, tačiau egzistuoja ir laisvos charakteristikos formos, vyksta darbuotojų savybių ir darbų nustatymas; trūkumai: vertinimas užima daug laiko, negalima lyginti gautų duomenų, darbuotojai skirstomi ị „labai gerus“, „gerus“ ir „blogus“, metodai orientuoti ị kelis tikslus. Komandinių metodų privalumai: išskiriamos stipriosios ir silpnosios darbuotojų pusès, metodai orientuoti ị specialius tikslus (tarp kurių gali būti ir organizacijos mokymosi aspektas), vertinama visa darbuotojų grupé vienu metu; trūkumai: darbuotojai suskirstomi i „geriausius“ ir „blogiausius“. Tačiau pagal išskiriamas darbuotojų vertinimo metodų savybes mokslininkai neakcentuoja jų ịtakos organizacijos mokymuisi, nors elgesys visada vienaip ar kitaip yra veikiamas vertinimo, dèl to ir ịtaka mokymuisi taikant skirtingus metodus gali būti skirtinga.

Pagrindinis darbuotojų veiklos vertinimo tikslas - didinti visų darbuotojų suinteresuotumą veiklos sèkme ir sukurti papildomas prielaidas jų našumui didinti (Bakanauskienė et al., 2006).

Efektyvus mokymasis yra ypač susijęs su organizacijos darbuotojų veiklos vertinimu. V. Darškuvienè, D. Kaupelytė \& N. Petkevičiūte (2008) teigia, kad mokymo procese, siekiant padidinti jo efektyvumą bei užtikrinti glaudesni mokymo sąryši su praktine vadybine veikla, vadybinès kompetencijos nustatymo bei ìvertinimo klausimai yra itin aktualūs.

B.T.Phillips (2003), B.Simonaitienė (2007) pateikia skirtingas mokymosi charakteristikas, dažniausiai papildytas P.Senge (2008) išskirtas penkias besimokančiai organizacijai būtinas disciplinas. Autoriai taip pat gilinosi ị tokius aspektus: klimatą ir kultūrą kaip mokymąsi skatinančią aplinką (Aksu \& Özdemir, 2005), mokymosi procesą (Stewart, 2001; Aksu \& Özdemir, 2005; Jucevičienè, 2007), kur išskiriamas vienos ir dviejų kilpų mokymasis, o D.Stewart (2001) pateikia dar vieną mokymosi lygmenị - trijų kilpų mokymąsi. Be to, nagrinejjamas individualus ir organizacinis mokymasis (Stewart, 2001; Andrzejczak, 2004; Aksu \& Özdemir, 2005; Phillips, 2003). Taip pat nagrinèta besimokančios organizacijos struktūra (Simonaitienè, 2007; Sakalas \& Venskus, 2007), bei jos privalumai, nauda, pasireškianti per mokymo-mokymosi rezultatus (Jewell, 2002; Baležentis, 2008). Tinkama organizacijos struktūra, kaip įrodo M.M.Yasin \& W.T.Zimmerer (1995), skatina kelti paslaugų kokybę.

R.Hopeniene ir kiti (2010), A.Malakauskaite \& V.Navickas (2010), B.K. A. Aivaz ir D. P. C Vancea (2009), B.Savrina ir kiti (2008), M.Koneenik \& M.Ruzzier (2008); pastebi, kad auga turizmo ir laisvalaikio sporto paslaugu sektorius. Tolimesniam sektoriaus turizmo ir laisvalaikio sporto paslaugu augimui reikalingas geras žinių valdymas bei gerai paruošti vadybos specialistai (Auruskeviciene et al., 2010; Kazlauskaite et al., 2009; Urban, 2009; Kersiene \& Savaneviciene, 2009; Kilijoniene et al., 2010;).

Darbuotojų igytos žinios daro tiesioginę įtaką konkurencingumui bei teikiamų paslaugų kokybei, (Martinkus et al., 2009; Snieska \& Bruneckiene, 2009;Navickas \& Malakauskaite, 2009; Liepe \& Sakalas, 2008; Jasinskas \& Simanaviciene, 2008; Snieska, 2008; Melnikas, 2008). 
Žmonès yra pagrindiniai veikẻjai žinių visuomenèje. Vertingiausia - žmogaus gebèjimas nuolat besikeičiančioje aplinkoje naudoti žinias veiksmingai ir protingai. Nuolatinis švietimas ir mokymas yra geriausias būdas priimti permainų iššūkius.

Apžvelgus atliktus tyrimus, mokymosi bei darbuotojų vertinimo klausimais, galima teigti, kad dabartiniais laikais organizacijoje ypač svarbu atlikti darbuotojų vertinimą ir nustatyti jo ryšį su mokymusi. Šiam tikslui, remdamiesi mokslinès literatūros analize sukūreme teorini Darbuotojų vertinimo ịtakos organizacijos mokymuisi teorinị modelį (žr. 1 pav.). Modelyje daroma prielaida, kad komandiniai darbuotoju vertinimo metodai laisvalaikio sporto klubuose labiau ịtakoja besimokančios organizacijos bruožu charakteristikas, nei individualūs darbuotojų vertinimo metodai.

Pateiktame modelyje matome individualius ir komandinius darbuotojų vertinimo metodus (išskirta remiantis - Pundzienė, 2002; Kumpikaitè, 2003; Gimžauskienė, 2004; Bakanauskienè et al., 2006; Tubutienė \& Morkūnaitè, 2008; Zuzevičiūtè \& Teresevičius, 2008) ir besimokančios organizacijos bruožus (sudaryta remiantis - Stewart, 2001; Phillips, 2003; Andrzejczak, 2004; Tamasevicius \& Jasinskas, 2004; Aksu \& Özdemir, 2005; Gaputienè, 2005; Simonaitienè, 2007; Sakalas \& Venskus, 2007).

\begin{tabular}{|c|c|c|}
\hline \multicolumn{2}{|r|}{$\begin{array}{l}\text { VEIKLOS VERTINIMO } \\
\text { METODAI }\end{array}$} & $\begin{array}{c}\text { BESIMOKANČIOS ORGANIZACIJOS } \\
\text { BRUOŽAI }\end{array}$ \\
\hline \multirow{6}{*}{ } & 360 laipsniu grĭ̌̆tamojo ryšsio & Mokymuisi tinkama aplinka, klimatas \\
\hline & Individnalans vertinimo & Organizacijos nariu bendravimas ir bendradarbiavimas \\
\hline & Laisvi (nestruktürizuoti) & Reakcija i visuomenès ir aplinkos poreikius \\
\hline & Aprašomieji (kokybiniai) & $\begin{array}{c}\text { Organizacijos narių mokymasis, švietimas, žiniu kaupimas, } \\
\text { orientuotas ị konkrečiu tikslụ siekima }\end{array}$ \\
\hline & Kombinuotieji (tarpiniai) & Vizijos, misijos, strategijos formavimas, organizuojamas kaip \\
\hline & Kiekybiniai & mokymosi procesas \\
\hline \multirow{4}{*}{ 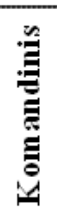 } & \multirow{4}{*}{ Lyginamojo vertinimo } & Atvira organizacija, plečianti savo efektyvumo ribas \\
\hline & & Nuolat besimokanti organizacija \\
\hline & & 3-jų kilpų mokymasis \\
\hline & & $\begin{array}{c}\text { Efektyvūs žiniu dalïjmosi procesai taikant naujausias } \\
\text { informacijos perdavimo technologijas }\end{array}$ \\
\hline
\end{tabular}

1 pav. Darbuotojų vertinimo įtakos organizacijos mokymuisi teorinis modelis

Darbuotojų veiklos ịvertinimas, jo ryšys su mokymusi, kaip mokejjimas greitai prisitaikyti prie kintančių sąlygų, pastovus tobulëjimas, psichologiniai veiksniai ir vidinès nuostatos bei kitos besimokančiai organizacijai priskiriamos savybès, gali stipriai pagerinti organizacijų konkurencingumą.

\section{Darbuotojų vertinimo įtaka organizacijos mokymuisi Alytaus laisvalaikio sporto klubuose: praktinis aspektas}

Tyrimo duomenims surinkti naudojomès anketinès apklausos metodu. Anketa sudaryta, remiantis atliktais moksliniais darbais, darbuose naudotomis anketomis (Gaputienè, 2005; Kumpikaitè, 2003; Tubutienė ir Morkūnaitė, 2008; Zuzevičiūtè ir Teresevičius, 2008; Gimžauskienė, 2004; Bakanauskienė, 2005 ir kt.). Anketoje naudojami klausimai su galimais atsakymų variantais, kada respondentas turi pasirinkti keletą, jo situaciją atspindinčių variantų, klausimai sudaryti Likerto skalès (naudojama nuostatoms tirti ir leidžia respondentui išsakyti savo nuomonę, kiek jis sutinka arba nesutinka su tam tikru teiginiu) principu, kada respondentas kiekvieną atsakymo variantą turi ịvertinti 4 balų skalëje, pagal svarbumą jam. Likerto 4 balų skale pasirinkta remiantis V. Kumpikaitès (2003) daktaro disertacijoje „Personalo ugdymo sistemos vertinimas“ naudota anketa, atsisakant atsakymo varianto „nežinau“. Organizacijoje, kuri siekia veiklos efektyvumo, svarbu ịvertinti ne tik veiklos vertinimo ir mokymosi ypatumus, tačiau atskleisti ir jų sąsajas. Todèl šiame poskyryje pateiksime veiklos vertinimo ir organizacijos mokymosi palyginimus bei vienu priklausomybę nuo kitų. 


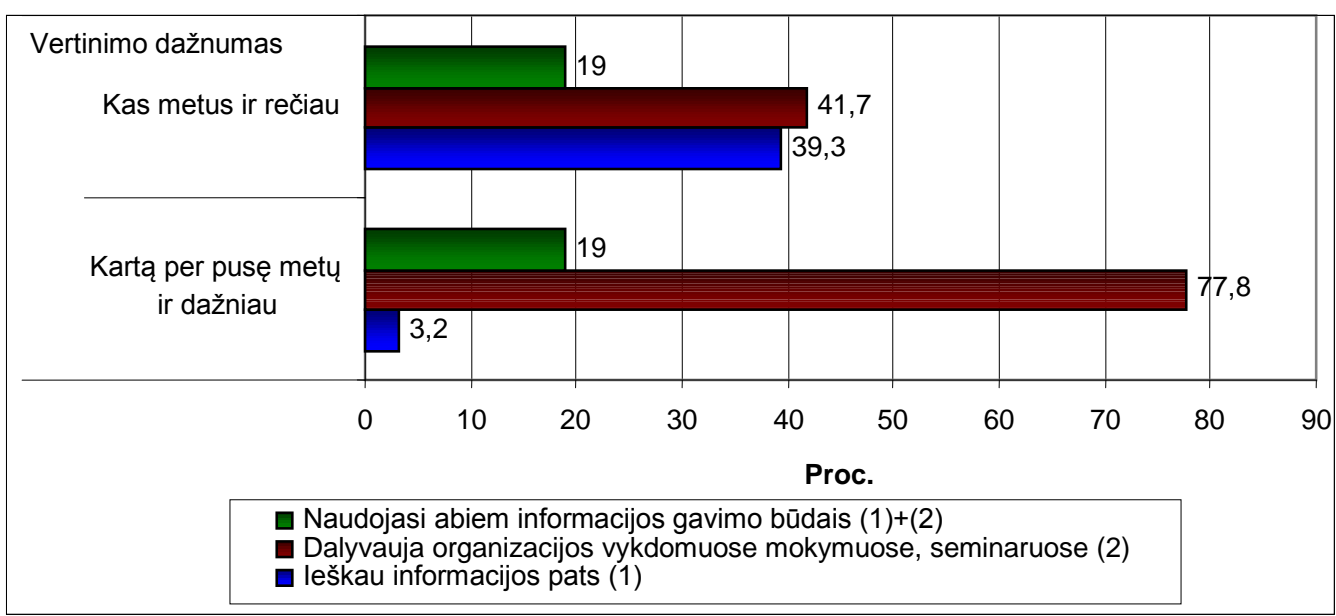

2 pav. Ryšio tarp vertinimo dažnumo ir naujos informacijos ịgijimo būdų procentinis pasiskirstymas

Tyrimo metu aiškinomės, kokiais būdais tiriamieji igyja naujų žinių, kuomet veiklos vertinimas atliekamas kas metus ir rečiau arba kartą per pusę metų ir dažniau (2 pav.).

Tyrimo rezultatai rodo, kad kuo dažniau yra vertinama laisvalaikio sporto klubų darbuotoju veikla, tuo rečiau tiriamieji ieško informacijos patys. Penktadalis apklaustuju teigè, jog naujos informacijos igyja ir ieškodami jos patys, ir dalyvaudami ịvairiuose mokymuose. Kas metus ir rečiau vertinami darbuotojai pagal naujų žinių igijimo būdą pasiskirsto tolygiai: ieško informacijos patys - 39,3 proc. dalyvauja organizacijos vykdomuose mokymuose, seminaruose $-41,7$ proc. Tai reiškia, kad veiklos vertinimo dažnumas turi ịtakos darbuotojų pasirinkimui igyjant naujų žinių kadangi tie, kurie vertinami dažniau žymiai daugiau dalyvauja organizacijos vykdomuose mokymuose.

Vertindami teoriniame modelyje pateiktus ryšius, pateikiame struktūrizuotų ir aprašomųų veiklos vertinimo metodų sąsają su organizacijoje vykstančių atliktų darbų analizès procesu (3 pav.), iš visų komandinių ir individualių metodų išskirti šie, nes Alytaus laisvalaikio sporto klubuose jie taikomi dažniau už kitus metodus.

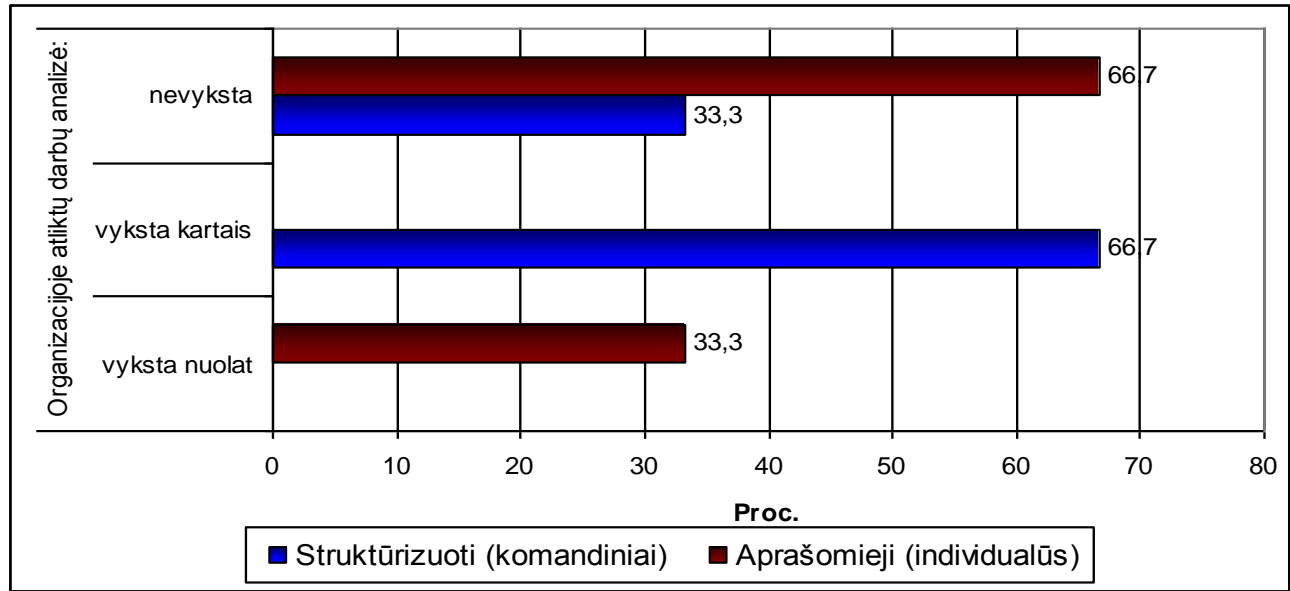

3 pav. Ryšio tarp dažniausiai taikomų struktūrizuotų, aprašomujų veiklos vertinimo metodų ir atliktų darbų analizès procentinis pasiskirstymas

Aukščiau esančiame paveiksle matome, kad atliekant vertinimą naudojant struktūrizuotus metodus, klaidos organizacijoje dažniausiai analizuojamos, kai turi pasekmių (66,7 proc.). Šis rodiklis rodo, kad atliktų darbų analizė vyksta ganètinai dažnai ir tuomet, kai darbuotojai yra vertinami pagal atskirų rodiklių svarbą. Tuo tarpu tokia pati dalis apklaustujų darbuotojų, kurie vertinami naudojant aprašomuosius metodus teigè, kad praeities klaidų neanalizuoja. Todèl darome išvadą, kad tirtose organizacijose atliktų darbų analizė vyksta kartais arba išvis nevyksta. Tačiau komandiniai (struktūrizuoti) vertinimo metodai turi daugiau įtakos atliekant darbų analizę organizacijoje.

Toliau pateiksime minètų veiklos vertinimo metodų ir žinių dalijimosi būdų sąsają (4 pav.). Pateikti rezultatai rodo, kad struktūrizuoti (komandiniai) ir aprašomieji (individualūs) veiklos vertinimo metodai 
labiau nulemia praktišką žinių taikymą organizacijoje (66,7 proc.) lyginant su žinių raiška žodžiais, skaičiais ir simboliais. Naujos žinios - žodžiais, skaičiais, simboliais, - kitiems organizacijos darbuotojams išreiškiamos dažniausiai vertinant aprašomuoju metodu. Tuo tarpu naudojant struktūrizuotus metodus žiniu raiška abiem minètais būdais vyksta tarp 33,3 procentų laisvalaikio sporto klubų darbuotojų. Tai perša išvadą, kad struktūrizuoti ir aprašomieji vertinimo metodai labiau teigiamai veikia praktišką žinių raišką organizacijoje. Tačiau komandiniai metodai labiau praktikuojami laisvalaikio sporto klubų darbuotojų.

Alytaus laisvalaikio sporto klubuose dažniausiai veiklos vertinimo funkciją atlieka tiesioginis vadovas, tačiau trūksta žinių pateikimo apie vertinimo kriterijus darbuotojams. Tai neigiamai veikia darbuotojų požiūrị ị vertinimo procesą.

Kita itin svarbi priklausomybė tarp mokymosi bruožų ir veiklos vertinimo metodų pateikta 18-oje lentelejje. Tiriami asmenys mokymosi bruožus vertino: 1 - nevyksta, 2- vyksta kartais, 3 - vyksta dažnai, 4 vyksta visada, atlikome individualaus ir komandinio vertinimo bei atskirų organizacijos bruožų sąsajas (visus Stjudento testu gautus reikšmingumus patikrinome Mano-Vitnio testu, kuris tinka mažų imčių palyginimui).

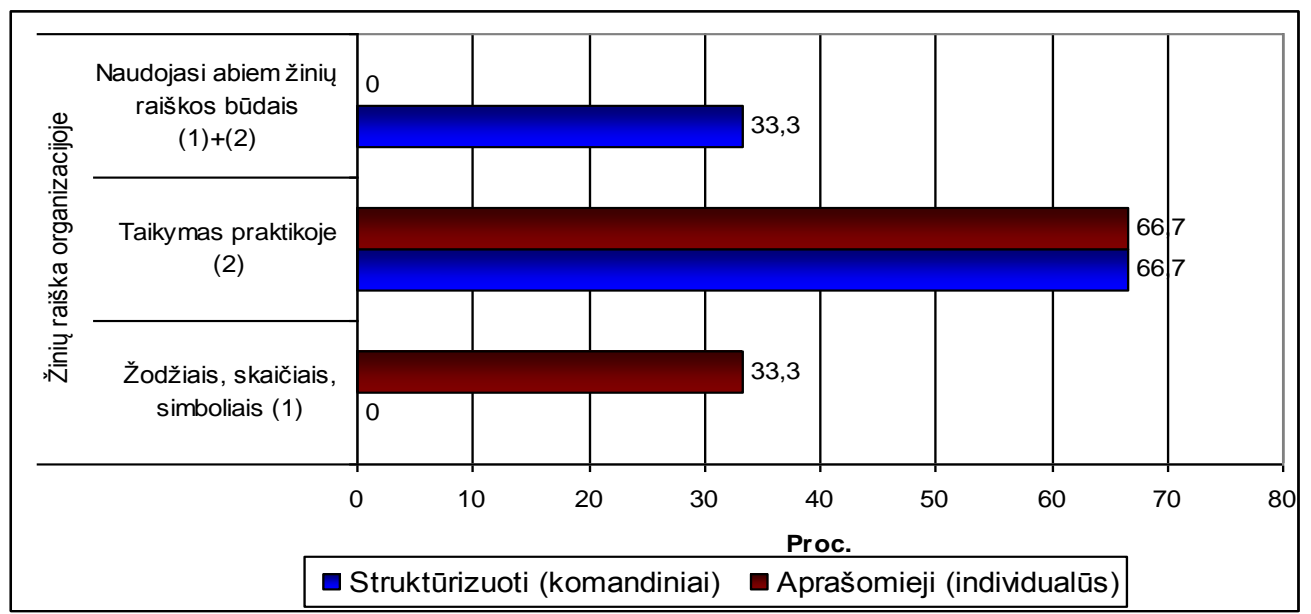

4 pav. Ryšio tarp dažniausiai taikomų struktūrizuotų, aprašomujų veiklos vertinimo metodų ir žinių raiškos organizacijoje procentinis pasiskirstymas

1-oje lentelejje matome, kad komandinio vertinimo balų vidurkis buvo reikšmingai $(\mathrm{p}>0,05)$ didesnis, vertinant reakciją $\mathfrak{i}$ visuomenès ir aplinkos poreikius, organizacijos narių mokymasis, švietimas, žiniu kaupimas, orientuotas ị konkrečių tikslų siekimą bei organizacijos atvirumas, plečiant savo aktyvumo ribas.

1 lentelė. Darbuotojų poreikiai bei motyvavimo priemonės skirtinguose karjeros etapuose

\begin{tabular}{|c|c|c|c|}
\hline \multirow{2}{*}{ Esminiai organizacijos bruožai } & \multicolumn{2}{|c|}{ Metodai, V(SN) (balai) } & \multirow[b]{2}{*}{ p reikšmė } \\
\hline & Individualus & Komandinis & \\
\hline Mokymuisi tinkama aplinka, klimatas & $3,63(0,74)$ & $3,5(0,58)$ & 0,80 \\
\hline Organizacijos narių bendravimas ir bendradarbiavimas & $2,88(0,64)$ & $0,25(0,96)$ & 0,40 \\
\hline Reakcija ị visuomenės ir aplinkos poreikius & $2,88(0,64)$ & $\mathbf{3 , 7 5}(0,5)$ & $\mathbf{0 , 0 4}$ \\
\hline $\begin{array}{l}\text { Organizacijos narių mokymasis, švietimas, žinių } \\
\text { kaupimas, orientuotas į konkrečių tikslų siekimą }\end{array}$ & $3,28(0,74)$ & $3,95(0,31)$ & 0,04 \\
\hline $\begin{array}{l}\text { Vizijos, misijos, strategijos formavimas, organizuojamas } \\
\text { kaip mokymosi procesas }\end{array}$ & $2,88(1,24)$ & $3,25(0,96)$ & 0,60 \\
\hline Atvira organizacija, plečianti savo efektyvumo ribas & $3,1(0,52)$ & $3,95(0,31)$ & $\mathbf{0 , 0 1}$ \\
\hline Nuolat besimokanti organizacija & $3,63(0,74)$ & $3,95(0,31)$ & 0,20 \\
\hline $\begin{array}{l}\text { Efektyvūs žinių dalijimosi procesai taikant naujausias } \\
\text { informacijos perdavimo technologijas }\end{array}$ & $3,75(0,46)$ & $3,25(0,5)$ & 0,10 \\
\hline Bendras balas: & 26,03 & 25,85 & - \\
\hline
\end{tabular}


Individualus vertinimas labiau atsispindi analizuojant šiuos tiriamujų organizaciją atitinkančius bruožus: mokymuisi tinkama aplinka, klimatas, organizacijos nariu bendravimas ir bendradarbiavimas, efektyvūs žinių dalijimosi procesai taikant naujausias informacijos perdavimo technologijas. $\mathrm{O}$ tai reiškia, kad atliekant komandini vertinimą apklaustieji pažymi, kad organizacijoje pradeda daugiau ryškèti minèti ir reikšmingai besiskiriantys besimokančios organizacijos bruožai. Savo ruožtu išskiriami ir ryškiausi individualaus vertinimo metodų įtakojami bruožai. Tai reiškia, kad komandinis vertinimas yra efektyvesnis laisvalaikio sporto klubams reaguojant ị visuomenès poreikius, vykstant organizacijos narių mokymuisi bei organizacijos veiklai darantis efektyvesnei. $\mathrm{O}$ individualus vertinimas - esant tinkamai mokymosi aplinkai ir klimatui, vykstant darbuotojų bendravimo ir bendradarbiavimo procesams bei nuolat keičiantis žiniomis, pasitelkiant naujausias technologijas. Tačiau pažvelgę ị individualaus ir komandinio vertinimo bendrą balą, matome, kad jis praktiškai vienodas. Šis faktas byloja, kad tiek individualaus, tiek komandinio vertinimo metodo taikyme svarbu, kad pats vertinimas būtų atliktas tinkamai ir darbuotojas jaustųsi ịvertintas teisingai. Tinkamai taikomi darbuotojo įvertinimo metodai teigiamai įtakoja organizacijos mokymąsi.

Daugiau negu pusė nagrinètų mokymosi bruožų labiau ryškėja atliekant komandinį vertinimą, o trys iš jų (reakcija ị visuomenès ir aplinkos poreikius; organizacijos narių mokymasis, švietimas, žinių kaupimas, orientuotas ị konkrečių tikslų siekimą; atvira organizacija, plečianti savo efektyvumo ribas) reikšmingai skyrèsi nuo individualaus vertinimo. Struktūrizuoti metodai (komandinis lygmuo) turi daugiau įtakos analizuojant organizacijoje atliktus darbus ir išreiškiant naujai gautas žinias kitiems organizacijos darbuotojams praktiškai, nei aprašomieji (individualus lygmuo) metodai.

\section{Išvados}

1. Išskirti individualių metodų privalumai: aiškus vertintojų skaičius, darbuotojai vertinami kiekvienas individualiai, nustatytas griežtas kriterijų kompleksas. Tačiau tarp šio tipo vertinimo metodų yra ir trūkumų: vertinimas užima daug laiko, negalima lyginti gautų duomenų, darbuotojai skirstomi ị „labai gerus“, „gerus“ ir „blogus“, metodai orientuoti ị kelis tikslus. Komandinių metodų privalumai: išskiriamos stipriosios ir silpnosios darbuotojų pusès, metodai orientuoti ị specialius tikslus, tarp kurių gali būti ir organizacijos mokymosi aspektas. Kaip tik ši priežastis leidžia daryti prielaidą, kad komandiniai metodai galètų daryti didesnę teigiamą įtaką organizacijos mokymuisi. Tačiau jei šie komandiniai metodai taikomi netinkamai, tada pradès reikštis ir komandinių vertinimo metodų trūkumai, pavyzdžiui neteisingai darbuotojus suskirsčius i „geriausius“ ir „blogiausius“, neturėsime ir teigiamo darbuotojo vertinimo efekto organizacijos mokymuisi.

2. Alytaus laisvalaikio sporto klubuose dažniausiai taikomi komandiniai (struktūrizuoti) vertinimo metodai labiau ịtakoja atliktų darbų analizę organizacijoje, nei individualūs (aprašomieji) metodai. Taikant komandinius (struktūrizuotus) ir individualius (aprašomuosius) vertinimo metodus žinios darbe labiau taikomos praktiškai nei išreiškiamos žodžiais, skaičiais, simboliais; kuo dažniau vertinama darbuotojų veikla, tuo rečiau tiriamieji ieško informacijos patys. Atliekant komandinį vertinimą organizacijoje labiau ryškejja besimokančios organizacijos bruožai, nei įvertinus sąsają tarp bruožų, labiausiai atitinkančių organizaciją ir priimtiniausių mokymąsi skatinančių veiksnių. Tačiau nors ir skirtingu intensyvumu, bet visi nagrinèti veiklos vertinimo aspektai ịtakoja organizacinį darbuotojų mokymąsi, o ypatingai komandiniai darbuotojų veiklos vertinimo metodai.

3. Alytaus laisvalaikio sporto klubuose dažniausiai veiklos vertinimo funkciją atlieka tiesioginis vadovas, tačiau trūksta žinių pateikimo apie vertinimo kriterijus darbuotojams. Tai neigiamai veikia darbuotojų požiūrị i vertinimo procesą. Vertinimas dažniausiai atliekamas komandiniame lygmenyje specialiụjų metodų pagalba, tačiau neatmetami ir individualūs metodai, todèl vertinimo metodą reikètų pasirinkti kiekvienam laisvalaikio sporto klubui individualiai. Nustatytas teigiamas darbuotojų veiklos vertinimo poveikis žinių valdymui. Išvardinti aspektai turi įtakos organizacijos veiklos rezultatams, todèl darbuotojų veiklos vertinimo funkcijai reikia skirti ypatingą dėmesį, o ypač siekiant didinti konkurencini pranašumą.

\section{Literatūra}

1. Aivaz, K. A., \& Vancea, D. P. C. (2009). A Study of the Black Sea Tourism Companies Efficiency Using Envelope Techniques. Transformations in Business \& Economics, 8(3), 217-230.

2. Aksu, A., \& Özdemir, B. (2005). Individual learning and organization culture in learning organizations. Five star hotels in Antalya region of Turkey. Managerial Auditing Journal, 4, 422-441. 
3. Alonderienè, R., \& Bakanauskienè, I. (2004). Darbuotojų vertinimas komandose. Organizacijų vadyba: sisteminiai tyrimai, 30, $21-33$.

4. Andrzejczak, A. (2004). The Changing Role of Learning and Training in Polish Companies. Transformation in business and economics. 3(2), 124-137.

5. Auruskeviciene, V., Pundziene, A., Skudiene, V., Gripsrud, G., Nes, E. B., \& Olsson, U. H. (2010). Change of Attitudes and Country Image after Hosting Major Sport Events. Inzinerine Ekonomika-Engineering Economics, 21(1), 53-59.

6. Bakanauskienè, I., Balvočiūtè, R., \& Balčiūnas, S. (2006). Organizacijų mokymosi tyrimas vadybinèje praktikoje. Organizacijų vadyba: sisteminiai tyrimai, $37,37-46$.

7. Baležentis, A. (2008). Inovatyviųjų mokymo formų ir metodų taikymo galimybès žmogiškųjų išteklių vadyboje. Viešoji politika ir administravimas, 26, 97-104.

8. Darškuvienė, V., Kaupelytė, D., \& Petkevičiūtė, N. (2008). Vadybinès kompetencijos nustatymo galimybès mokymo procese. Organizacijų vadyba: sisteminiai tyrimai, 45, $17-28$.

9. Gaputienè, I. (2005). Žinių perdavimo sistemos plètojant tarptautinius įmonių tinklus. Daktaro disertacija, socialiniai mokslai, vadyba ir administravimas, 03 S. Kaunas: ISM.

10. Gimžauskienė E. (2004). Valdymo apskaitos metodų adaptavimas organizacijos veiklos vertinimo procese. Daktaro disertacija, socialiniai mokslai, vadyba ir administravimas, 03 S. Kaunas: Kauno technologijos universitetas.

11. Ginevicius, R., \& Ginevicjiene, V. (2009). The Compliance of Master's Degree Studies with the Economic Needs of the Country. Technological and Economic Development of Economy, 15(1), 136-153.

12. Grundey, D. (2008). TQM in university studies: Quality assessment and quality assurance in a Lithuanian University. Transformations in Business \& Economics, 7(2), 216-235.

13. Hopeniene, R., Railiene, G., \& Kazlauskiene, E. (2009). Potential of Virtual Organizing of Tourism Business System Actors. Inzinerine Ekonomika-Engineering Economics, (3), 75-85.

14. Yasin, M.M., \& Zimmerer, W.T. (1995). The role of benchmarking in achieving continuous service quality. International Journal of Contemporary Hospitality Management, 4, 27-32.

15. Jasinskas, E. (2008). Formation of the European agricultural support model: Reasons, principles and tendencies. Transformations in Business \& Economics, 7(2), 55-68.

16. Jasinskas, E., \& Simanaviciene, Z. (2008). Government's support for farmers' knowledge dissemination and its improvement. Inzinerine Ekonomika-Engineering Economics, (3), 67-72.

17. Jewell, B. R. (2002). Integruotos verslo studijos. Vilnius: The Baltic Press.

18. Jucevičienè, P. (2009). The alternative trajektories towards the learning organization. Socialiniai mokslai, 2 (64), 26-34.

19. Kazlauskaite, R., Buciuniene, I., Turauskas, L., \& Salciuviene, L. (2009). A Comparative Study of Employee Empowerment in Danish and Lithuanian Hotels. Transformations in Business \& Economics, 8(2), 66-85.

20. Kersiene, K., \& Savaneviciene, A. (2009). The Formation and Management of Organizational Competence Based on Cross-Cultural Perspective. Inzinerine Ekonomika-Engineering Economics, (5), 56-65.

21. Kilijoniene, A., Simanaviciene, Z., \& Simanavicius, A. (2010). The Evaluation of Social and Economic Development of the Region. Inzinerine Ekonomika-Engineering Economics, 21(1), 68-79.

22. Kumpikaite V. (2003). Personalo ugdymo sistemos vertinimas. Daktaro disertacija, socialiniai mokslai, vadyba ir administravimas, $03 \mathrm{~S}$. Kaunas: Vytauto didžiojo universitetas.

23. Koneenik, M., \& Ruzzier, M. (2008). The customer's perspective on the tourism destination brand: A structural equation modeling study. Transformations in Business \& Economics, 7(1), 169-184.

24. Liepe, Z., \& Sakalas, A. (2008). The three-loop learning model appliance in new product development. Inzinerine Ekonomika-Engineering Economics, (3), 73-80.

25. Malakauskaite, A., \& Navickas, V. (2010). Relation between the Level of Clusterization and Tourism Sector Competitiveness. Inzinerine Ekonomika-Engineering Economics, 21(1), 60-67.

26. Martinkus, B., Stoskus, S., \& Berzinskiene, D. (2009). Changes of Employment through the Segmentation of Labour Market in the Baltic States. Inzinerine Ekonomika-Engineering Economics, (3), 41-48.

27. Melnikas, B. (2008). Integration Processes in the Baltic Region: the New Form of Regional Transformations in the European Union. Inzinerine Ekonomika-Engineering Economics, (5), 54-64.

28. Navickas, V., \& Malakauskaite, A. (2009). The Possibilities for the Identification and Evaluation of Tourism Sector Competitiveness Factors. Inzinerine Ekonomika-Engineering Economics, (1), 37-44. 
29. Neverauskas, B., \& Stankevicius, V. (2008). Project Management: Research and Studies at the Faculty of Economics and Management of Kaunas University of Technology. Inzinerine Ekonomika-Engineering Economics, (4), 59-66.

30. Örtenblad, A. (2001). On differences between organizational learning and learning organization. The Learning Organization. Conceptual Paper, 3 125-133.

31. Phillips, B.T. (2003). A four-level learning organization benchmark implementation model. The Learning Organization. Research paper, 2, 98-105.

32. Pundzienè, A. (2002). Profesinio mokymo institucija kaip besimokanti organizacija: problemos ir kaitos gairès. Profesinis rengimas: tyrimai ir realijos, 4, $74-83$.

33. Sakalas, A., \& Venskus, R. (2007). Interaction of Learning Organization and Organizational Structure. Inzinerine Ekonomika-Engineering Economics 3, 65-70.

34. Savrina, B., Grundey, D., \& Berzina, K. (2008). Cooperation - The form of sustainable tourism industry in Latvia. Technological and Economic Development of Economy, 14(2), 151-161.

35. Senge, P. (2008). Besimokanti mokykla. Vilnius.

36. Serafinas, D., \& Ruževičius, J. (2009). Aukštujų mokyklų veiklos tobulinimo pokyčių kontekste ịžvalgos. Ekonomika ir vadyba, (14), 1091-1099.

37. Simonaitienè, B. (2007). Mokyklos - besimokančios organizacijos vystymas. Mokslo studija. Kaunas: Technologija.

38. Stewart, D. (2001). Reinterpreting the learning organisation. The Learning Organization, 4, 141-152.

39. Snieska, V. (2008). Research into International Competitiveness in 2000-2008. Inzinerine Ekonomika-Engineering Economics, (4), 29-41.

40. Snieska, V., \& Bruneckiene, J. (2009). Measurement of Lithuanian Regions by Regional Competitiveness Index. Inzinerine Ekonomika-Engineering Economics, (1), 45-57.

41. Stukalina, Y. (2010). Using Quality Management Procedures in Education: Managing the Learner-Centered Educational Environment. Technological and Economic Development of Economy, 16(1), 75-93.

42. Slizyte, A., Bakanauskiene, I. (2007). Designing performance measurement system in organization. Organizaciju vadyba: sisteminiai tyrimai, $43,135-148$.

43. Tamasevicius, V., Jasinskas, E. (2004). Motives Influencing Organization Learning. Engineering economics/Inžinerine ekonomika, 1 (36), 57 - 61.

44. Tubutienè, V., Morkūnaitè, S. (2008). Organizacinio mokymosi modeliai besimokančioje organizacijoje. Ekonomika ir vadyba: aktualijos ir perspektyvos, 1 (10), $200-211$.

45. Urban, W. (2009). Service Quality Gaps and Their Role in Service Enterprises Development. Technological and Economic Development of Economy, 15(4), 631-645.

46. Zafiropoulos, C., \& Vrana, V. (2008). Service quality assessment in a Greek Higher Education Institute. Journal of Business Economics and Management, 9(1), 33-45.

47. Zuzevičiūtè, V., Teresevičius, T. (2008). Besimokančios organizacijos kūrimo prielaidos. Organizacijų vadyba: sisteminiai tyrimai, 45, 115 - 126. 